\title{
LINGKAR LENGAN ATAS IBU HAMIIL AKAN MEMPENGARUHI PENINGKATAN BERAT BADAN BAYI LAHIR DI BPS ARTININGSIH SURABAYA
}

\author{
Nurul Kamariyah, Musyarofah \\ Fakultas Keperawatan dan Kebidanan \\ Universitas Nahdlatul Ulama Surabaya - Jl Smea 57 Surabaya \\ Email : nurulkamariyah@unusa.ac.id
}

\begin{abstract}
: the relationship of the upper arm circumference pregnant women with birth weight Artiningsih BPS Surabaya. Most women experience upper arm circumference is less than the normal limit . Based on preliminary data from 15 pregnant women found 10 women experience MUAC less than the normal limit . 5 women experience LILA normal limits. The purpose of analyzing the relationship of the upper arm circumference pregnant women with birth weight Artiningsih BPS Surabaya . This study uses an analytical method with cross sectional approach . Population is all mothers giving birth are recorded in BPS Artiningsih Surabaya by 33 respondents total sample of 30 respondents. Mechanical sampling probability sampling with simple random sampling. Using independent variable circumference of the upper arm , the dependent variable birth weight. The instrument uses secondary data then analyzed by Spearman Rank $\quad=0.05$ which means there is a connection upper arm circumference pregnant women with birth weight in BPS Artiningsih Surabay. The results showed 33 pregnant women most ( $66.7 \%$ ) upper arm circumference is less, and most ( $54.1 \%$ ) gave birth to babies with low birth weight, as well as the results of Spearman Rank p = 0.000 less than Conclusions LILA increasingly normal pregnant women increasingly gained normal birth weight . expected to pregnant women who have a MUAC $<23.5$ $\mathrm{cm}$ were able to increase the consumption of better nutrition.
\end{abstract}

Abstrak Hubungan Lingkar Lengan Atas Ibu Hamil Dengan Berat Badan Bayi Lahir BPS Artiningsih Surabaya. Sebagian besar ibu hamil mengalami lingkar lengan atas kurang dari batas normal.Berdasarkan data awal dari 15 ibu hamil ditemukan $10 \mathrm{ibu}$ mengalami LILA kurang dari batas normal. 5 ibu mengalami LILA batas normal. Tujuan menganalisis hubungan lingkar lengan atas ibu hamil dengan berat badan bayi lahir BPS Artiningsih Surabaya. Penelitian ini menggunakan metode analitik dengan pendekatan cross sectional.Populasi adalah semua ibu melahirkan yang tercatat di BPS Artiningsih Surabaya sebesar 33 responden jumlah sample 30 responden. Teknik pengambilan sampel secara probability sampling dengan simple random sampling.Menggunakan Variabel independent lingkar lengan atas, variabel dependent berat badan bayi lahir. Instrumen menggunakan data sekunder kemudian dianalisis secara Rank Spearman. Hasil penelitian menunjukkan dari 33 ibu hamilsebagian besar $(66,7 \%)$ lingkar lengan atas yang kurang, dan sebagian besar $(54,1 \%)$ melahirkan bayi dengan berat badan bayi rendah, serta hasil Rank Spearman $\mathrm{p}=0,000$ lebih kecil dari = 0,05 yang artinya ada hubungan lingkar lengan atas ibu hamil dengan berat badan bayi lahir di BPS Artiningsih Surabaya Simpulan semakin normal LILA ibu hamil semakin didapatkan berat badan bayi lahir normal. diharapkan ibu hamil yang mempunyai LILA $<23,5 \mathrm{~cm}$ mampu meningkatkan konsumsi nutrisi yang lebih baik. 
Key words: lingkar lengan, berat bayi

\section{PENDAHULUAN}

Lingkar Lengan Atas (LiLA) adalah suatu cara untuk mengetahui resiko kekurangan energi kronis pada Wanita Usia Subur (WUS). Pengukuran lingkar lengan atas tidak dapat digunakan untuk memantau perubahan status gizi dalam jangka pendek. Gizi ibu hamil adalah makanan atau zat-zat gizi yang di butuhkan oleh seorang ibu yang sedang hamil baik pada trimester I, trimester II, dan trimester III dan harus cukup jumlah dan mutunya dan harus di penuhi dari kebutuhan makan sehari-hari sehingga janin yang dikandungnya dapat tumbuh dengan baik serta tidak mengalami gangguan dan masalah(Kristianasari W,2010 ). Pada kenyataannya di BPS Artiningsih Surabaya terdapat sebagian besar ibu hamil yang mengalami lingkar lengan atas kurang dari batas normal. Dan sebagian besar bayi lahir dengan BBLR di BPS Artiningsih Surabaya.

Pada Juni 2015 dari 15 ibu hamil ada 10 atau sebagian besar ibu hamil mengalami lingkar lengan atas kurang dari batas normal, dan di temukan dari 15 bayi lahir terdapat 8 sebagian besar bayi lahir dengan BBLR di BPS Artiningsih Surabaya. Semua ibu hamil memerlukan adanya pemenuhan status gizi untuk ibu sendiri dan untuk perkembangan bayi yang dikandungnya. Meskipun semua orang di Indonesia sudah mengetahui manfaat gizi bagi ibu hamil namun sampai saat ini masih banyak ibu hamil yang mengalami lingkar lengan atas kurang dari normal sebagai indikator gizi kurang seperti Kurang Energi Kronis (KEK). Salah satucara untuk mengetahui apakah ibu hamil menderita lingkar lengan atas kurang dari $23,5 \mathrm{~cm}$ atau tidak, maka ibu hamil dikatakan mempunyai gizi kurang dan berisiko melahirkan bayi dengan Berat Bayi Lahir Rendah (BBLR). Dari data (Siti Cholilah) tahun 2014 di tempat BPS Kusmawati Surabaya. menunjukkan bahwa ibu hamil atau Wanita Usia Subur (WUS) menderita lingkar lengan atas kurang dari batas normal, masalah ini mengakibatkan pada saat hamil akan menghambat pertumbuhan janin sehingga menimbulkan resiko pada bayi dengan BBLR (Joeharno, 2008). Angka kematian bayi (AKB) di Indonesia masih sangat tinggi. Secara nasional berdasarkan analisa lanjut SDKI tahun 2012 angka BBLR sekitar 7,5\%. Angka ini lebih besar dari target BBLR yang ditetapkan pada sasaran program perbaikan gizi menuju Indonesia Sehat 2012 yakni maksimal 7\%. (IDAI, 2007). Persentase bayi berat lahir rendah di Jawa Timur pada tahun 2012 sebesar 2,26\% masih tinggi bila dibandingkan tahun 2011 sebesar $2,17 \%$ (Profil Dinas Kesehatan Provinsi Jawa Timur, 2011). Penyebab kematian bayi baru lahir adalah Bayi Berat Lahir Rendah (BBLR) sebanyak 226 bayi (36\%). Cacat bawaan sebanyak 210 bayi (33\%), kekurangan oksigen (asfiksia) sebanyak 199 bayi (31\%), sedangkan penyebab lain kematian bayi baru lahir disebabkan oleh sepsis (infeksi sistemik), kelainan bawaan dan trauma persalinan (Dinkes,2010). Ibu hamil dengan lingkar lengan atas kurang dari $23,5 \mathrm{~cm}$ mempunyai resiko 2,0087 kali untuk melahirkan BBLR dibanding dengan ibu yang mempunyai lingkar lengan atas lebih dari $23,5 \mathrm{~cm}$. Dari 15 orang yang melakukan pemeriksaan kehamilan 10 (70\%) orang mengalami lingkar lengan atas yang kurang dari $23,5 \mathrm{~cm}$ dan di 
temukan 8 bayi (30\%) bayi lahir dengan Berat Bayi Lahir Rendah (BBLR). (Joeharno 2010).

Faktor yang mempengaruhi BBL pada ibu hamil meliputi umur ibu hamil, Jarak Kehamilan/Kelahiran, paritas, Kadar Hemoglobin $(\mathrm{Hb})$, status gizi ibu hamil, Penyakit Saat Kehamilan,. Faktor yang berpengaruh pada lingkar lengan atas kurang dari normal mampu terjadinya berat bayi lahir rendah (BBLR) salah satunya disebabkan karena faktor pengetahuan . pengetahuan yang kurang baik terhadap konsumsi nutrisi saat hamil akan berpengaruh pada perkembangan lingkar lengan atas dengan berat badan bayi lahir (BBL) . lingkar lengan atas pada ibu hamil dapat menpengaruhi proses pertumbuhan janin, abortus, kematian neonatal, cacat bawaan, anemia pada bayi, lahir dengan berat badan rendah (BBLR), ibu dengan status gizi kurang sebelum hamil mempunyai resiko 4,27 kali untuk melahirkan bayi BBLR di bandingkan dengan ibu yang mempunyai status gizi baik ( normal ).( Joeharno, 2008). lingkar lengan atas yang kurang merupakan ukuran dari kurangnya nutrisi pada ibu hamil yang menyebabkan resiko dan komplikasi pada ibu pada saat hamil maupun bersalin antara lain : anemia, berat badan ibu tidak bertambah secara normal. mudah terkena penyakit infeksi, persalinan sulit dan lama, persalinan sebelum waktunya, dan pendarahan setelah persalinan. lingkar lengan atas pada ibu hamil dapat mempengaruhi proses pertumbuhan janin, abortus, kematian neonatal, cacat bawaan, anemia pada bayi, lahir dengan berat badan rendah (BBLR), ibu dengan status gizi kurang sebelum hamil mempunyai resiko 4,27 kali untuk melahirkan bayi BBLR di bandingkan dengan ibu yang mempunyai status gizi baik (normal) (Joeharno,2008).
Upaya penanggulangan lingkar lengan atas yang baik dan berat badan bayi lahir normal 2500 - 4000 gram. Maka solusinya dengan memberikan penyuluhan yang dilakukan sejak awal pemeriksaan kehamilan dan setiap kali periksa kehamilan yang meliputi kebutuhan gizi cukup dan seimbang, rutin melakukan pemeriksaan, dan istirahat cukup dan pemberian leaflet. (Kristiyanasari W, 2010)

\section{METODE}

Penelitian ini menggunakan metode analitik dengan pendekatan cross sectional. Populasi dalam penelitian ini adalah semua ibu melahirkan yang tercatat di BPS Artiningsih Surabaya sebesar 33 orang. Sampel dalam penelitian ini adalah sebagian ibu yang melahirkan di BPS Artiningsih Surabaya yang sesuai dengan kriteria populasi dan bersedia menjadi responden sebesar 30 responden. Dalam penelitian ini menggunakan probability sampling, dengan jenis simple random sampling. Variabel independen adalah Lingkar Lengan Atas Ibu Hamil sedangkan variable dependennya adalah Berat Badan Bayi Lahir. Data dianalisis dengan Rank Sperman dengan tingkat kemakanaan adalah 0,05.

\section{HASIL PENELITIAN}

\section{a. Hasil}

1. Data Umum

a. Karakteristik Responden Berdasarkan Tingkat Pendidikan

Karakteristik responden berdasarkan tingkat pendidikan dapat dilihat pada tabel berikut :

Berdasarkan (UU RI 2003) jenjang pendidikan dikelompokkan menjadi 3 yaitu: pendidikan dasar (SD/MI, SMP/MTS atau sederajat), pendidikan menengah (SMA/SMK atau sederajat), dan pendidikan Tinggi (diploma dan sarjana) 
Tabel 1 Distribusi frekuensi responden berdasarkan tingkat pendidikan di BPS

\begin{tabular}{lccc}
\hline No. & Usia & Jumlah & Persentasi $(\%)$ \\
\hline 1. & $<20$ & 13 & 39,4 \\
2. & $21-35$ & 11 & 33,4 \\
3. & $>35$ & 9 & 27,2 \\
\hline & Jumlah & 33 & 100 \\
\hline
\end{tabular}

Artiningsih Surabaya bulan Juli 2015

Tabel di atas menunjukkan bahwa dari 33 responden sebagian besar $(69,7 \%)$ memiliki tingkat pendidikan Dasar SD / SMP Sederajat.

b. Karakteristik Responden Berdasarkan Pekerjaan

Karakteristik responden berdasarkan pekerjaan dapat dilihat pada tabel berikut :

Berdasarkan Saimin, J. 2006 yaitu : yang dimaksud ibu bekerja adalah wanita yang sudah bersuami dalam kehidupan atau kegiatan sehari-harinya bekerja di luar rumah mencari nafkah baik sebagai pegawai negeri ataupun swasta, sedangkan ibu yang tidak bekerja adalah wanita yang sudah bersuami dalam kehidupan atau No Pekerjaan Frekuensi Presentase

\begin{tabular}{llcc} 
& & $(\%)$ \\
\hline 1. & Bekerja & 10 & 30,3 \\
2. & Tidak bekerja & 23 & 69,7 \\
\hline & Jumlah & 33 & 100 \\
\hline
\end{tabular}

kegiatan sehari-hari hanya melakukan tugas-tugas rumah tangga saja.

Tabel Distribusi frekuensi responden berdasarkan pekerjaan di BP Artiningsih Surabaya bulan Juli 2015

Sumber : Data Primer Juni 2015

Tabel di atas menunjukkan bahwa dari 33 responden sebagian besar $(69,7 \%)$ responden tidak bekerja.

c. Umur ibu hamil
Menurut Mutalazimah (2010) dalam Setianingrum (2007) menyatakan bahwa pembagian umur dibagi menjadi 3 kategori : usia tidak aman ( $<20$ tahun),

\begin{tabular}{|c|c|c|c|}
\hline No & Pendidikan & Frekuensi & Persentase (\%) \\
\hline 1. & Dasar & 23 & 69,7 \\
\hline 2. & Menengah & 6 & 18,2 \\
\hline 3. & Tinggi & 4 & 12,1 \\
\hline & Jumlah & 33 & 100 \\
\hline
\end{tabular}

usia aman (21-35 tahun) dan usia tidak aman ( $>35$ tahun).

Tabel Distribusi frekuensi umur ibu hamil di BPS Artiningsih Surabaya

Bulan Juni 2015

Sumber : Data Sekunder periode Juni 2015

Tabel diatas menunjukkan dari 33 responden pada umur ibu hamil hampir setengahnya $(39,4 \%)$ ibu hamil yang melahirkan umur di bawah 20 tahun.

d. Jarak Kehamilan/Kelahiran

Pengantar Menurut Dinkes provjatim (2010) menyatakan kehamilan yang perlu diwaspadai adalah jarak persalinan terakhir dengan awal kehamilan sekarang $\leq 2$ tahun merupakan jarak yang terlalu dekat dan $>2$ Tahun merupakan jarak yang aman.

Tabel Distribusi frekuensi jarak kehamilan / kelahiran di BPS Artiningsih Surabaya Bulan Juni 2015

\begin{tabular}{cccc}
\hline No. & $\begin{array}{c}\text { Jarak } \\
\text { Kehamilan/Kelahiran }\end{array}$ & Jumlah & $\begin{array}{c}\text { Peresentasi } \\
(\%)\end{array}$ \\
\hline 1. & Jarak terlalu dekat & 24 & 72,8 \\
2. & Jarak aman & 9 & 27,2 \\
\hline & Jumlah & 33 & 100
\end{tabular}

Sumber : Data Sekunder periode Juni 2015

Tabel diatas menunjukkan dari 33 responden pada jarak kehamilan ibu hamil sebagian besar (72,8\%) melahirkan dengan jarak yang terlalu dekat. 
e. Paritas

Pendapat Dinkes provjatim (2010) pembagian paritas dikategorikan menjadi 3 kriteria. Yaitu Primipara jika melahirkan 1 kali, Multipara jika melahirkan 2-4, dan grande multipara jika melahirkan lebih dari $>4$.

Tabel Distribusi frekuensi paritas di BPS Artiningsih Surabaya Bulan Juli 2015

No. Paritas Jumlah Peresentasi

1. $\quad$ Primipara $\quad 8 \quad 24,2$

2. Multipara $\quad 8 \quad 24,2$

3. Grandemultipara $17 \quad 51,6$ Jumlah $33 \quad 100$

Sumber : Data Sekunder periode Juni 2015

Tabel diatas menunjukkan bahwa dari 33 responden hamper sebagian besar ibu hamil $(51,6 \%)$ melahirkan $>4$ anak.

\section{Data Khusus}

Data ini terdiri dari lingkar lengan atas dan berat badan bayi lahir pada ibu melahirkan di BPS Artiningsih Surabaya pada bulan Juni 2015

a. Lingkar lengan atas

Menurut Supariasa (2012) Lingkar lengan atas ibu hamil di bagi menjadi 3 kategori yaitu LILA kurang $(<23,5$ $\mathrm{cm})$, LILA normal $(23,5 \mathrm{~cm})$, LILA lebih $(28,5 \mathrm{~cm})$.

Tabel Distribusi frekuensi kejadian lingkar lengan atas di BPS.

Artiningsih

Surabaya pada tanggal Juni 2015.

\begin{tabular}{clccc}
\hline No & LILA & Jumlah & $\begin{array}{c}\text { Persentasi } \\
(\boldsymbol{\%})\end{array}$ \\
\hline $\mathbf{1}$ & Kurang & 22 & 66,7 \\
$\mathbf{2}$ & Normal & 9 & 27,3 \\
$\mathbf{3}$ & Lebih & 2 & 6 \\
\multicolumn{2}{c}{ Jumlah } & 33 & $\alpha$ & 100 \\
\hline
\end{tabular}

Sumber : Data Sekunder periode Juni 2015

Tabel diatas menunjukkan dari total 33 responden sebagian besar $(66,7 \%)$ responden mempunyai lingkar lengan atas adalah kurang.

b. Berat badan bayi lahir

Tabel Distribusi frekuensi berat badan bayi lahir di BPS Artiningsih Surabaya Bulan Juni 2015

\begin{tabular}{llcc}
\hline No. & $\begin{array}{c}\text { Berat badan } \\
\text { bayi lahir }\end{array}$ & Jumlah & $\begin{array}{c}\text { Presentasi } \\
(\%)\end{array}$ \\
\hline 1. & Lebih & 3 & 9,1 \\
2. & Normal & 12 & 36,4 \\
3. & Rendah & 18 & 54,5 \\
\hline & Jumlah & 33 & 100
\end{tabular}

Sumber : Data Sekunder periode Juni 2015

Tabel diatas menunjukkan dari 33 responden persalinan normal pada ibu hamil sebagian besar $(54,5 \%)$ melahirkan bayi dengan berat badan bayi lahir rendah.

\section{c. Rekapitulasi Tabulasi Silang}

Tabel Distribusi tabulasi silang antara lingkar lengan atas dengan berat badan bayi lahir di BPS Artiningsih Surabaya Bulan Juni 2015

\begin{tabular}{|c|c|c|c|c|c|c|c|}
\hline \multirow[t]{3}{*}{ LILA } & \multicolumn{6}{|c|}{ BBL } & \multirow{3}{*}{$\begin{array}{c}\text { Total } \\
(\%)\end{array}$} \\
\hline & \multicolumn{2}{|c|}{ Rendah } & \multicolumn{2}{|c|}{ Normal } & \multicolumn{2}{|c|}{ Obesitas } & \\
\hline & & $\%$ & & $\%$ & & $\%$ & \\
\hline Kurang & 17 & $\begin{array}{l}77 \\
27\end{array}$ & 5 & $\begin{array}{l}22 \\
72\end{array}$ & 0 & 0 & 100 \\
\hline Normal & 1 & $\begin{array}{c}11, \\
11\end{array}$ & 7 & $\begin{array}{l}77 \\
77\end{array}$ & 1 & $\begin{array}{l}11 \\
11\end{array}$ & 100 \\
\hline Lebih & 0 & 0 & 0 & 0 & 2 & 100 & 100 \\
\hline Total & 18 & & 22 & & 3 & & \\
\hline
\end{tabular}

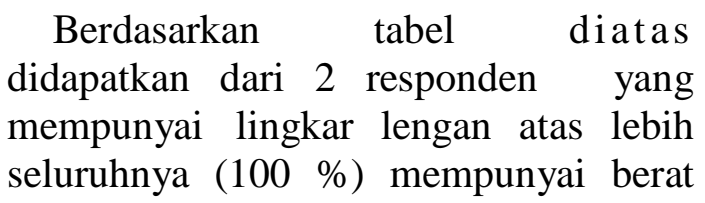


badan lahir obesitas. Hasil uji Rank Spearman mempunyai didapatkan nilai $\mathrm{p}=0,000$ dan $\quad=0,05$, berarti $\mathrm{p}<$ tabel maka $\mathrm{H}_{0}$ ditolak berarti ada Hubungan Lingkar Lengan Atas Ibu Hamil Dengan Berat Badan Bayi Lahir di BPS Artiningsih Surabaya.

\section{b. PEMBAHASAN}

\section{Lingkar Lengan Atas}

Berdasarkan hasil penelitian tabel 5.7 dari 33 responden di BPS Artiningsih Surabaya didapatkan sebagian besar $(66,7 \%)$ responden mengalami lingkar lengan atas kurang dari batas normal. pengukuran lingkar lengan atas pada kelompok wanita usia subur dengan cara untuk mendeteksi dini yang mudah dan dapat dilaksanakan oleh masyarakat awam untuk mengetahui adanya kelompok berisiko kekurangan energi kronis (KEK) pada wanita usia subur. suatu cara untuk mengukur lingkar lengan atas ibu hamil dengan menggunakan pita ukur mulai dari os akromion sampai os olikranon.

Hasil penelitian diatas berdasar tabel 5.1 sebagian besar $(69,7 \%)$ mempunyai pendidikan dasar. Seorang yang mempunyai pendidikan dasar kurang mampu untuk menganalisis informasi yang didapat, sehingga informasi yang didapat langsung dilakukan tanpa memikirkan efek samping yang akan terjadi. Contoh jika mereka mendapat informasi tentang makanan yang dikonsumsi ibu hamil untuk meningkatkan lingkar lengan atas adalah konsumsi nasi tanpa ikan, maka mereka akan langsung mengkonsumsi nasi tanpa ikan sesuai dengan informasi yang didapat. Selain hal itu ibu hamil yang berpendidikan dasar akan berpengaruh kepada pengetahuan seseorang. Pengetahuan yang kurang terhadap pemenuhan gizi ibu hamil akan berpengaruh kepada lingkar lengan atas yang akankurang. Hal ini sesuai pendapat Notoadmodjo 2006. Yang mengatakan bahwa pendidikan berpengaruh terhadap pengetahuan, pengetahuan akan berpengaruh kepada perilaku seseorang dan faktor pendidikan mempengaruhi pola makan ibu hamil, tingkat pendidikan yang lebih tinggi diharapkan pengetahuan atau informasi tentang gizi yang dimiliki lebih baik sehingga bisa memenuhi asupan gizinya (Supariasa, I.D.N. (2012).

Faktor lain dari pendidikan adalah pekerjaan. Berdasarkan hasil bahwa sebagian besar $(69,7 \%)$ tidak bekerja. Seseorang yang tidak bekerja, mereka tidak mempunyai penghasilan, orang yang tidak mempunyai penghasilan kurang mempunyai kemampuan untuk membeli makanan yang berlebih sesuai dengan gizi yang dibutuhkan. Hal ini akan membuat konsumsi makanan oleh ibu hamil akan berkurang yang akan mengakibatkan lila kurang. Ibu hamil kurang dari normal. Hal ini sesuai dengan teori Pekerjaan adalah sesuatu perbuatan atau melakukan sesuatu yang dilakukan untuk mencari nafkah guna untuk pemenuhan kehidupan terutama masalah makan dan tempat tinggal seorang yang bekerjanya akan lebih mampu untuk memenuhi kebutuhan hidupnya begitu juga sebab kurangnya (Saimin, J. 2006).

Selain faktor pendidikan dan pekerjaan faktor yang lain adalah pendapatan. Berdasarkan hasil tabel 5.3 Hampir seluruhnya $(75,8 \%)$ memiliki pendapatan < dari UMR $(<2.200 .000)$. Pendapatan seseorang akan mempengaruhi kebutuhan hidup seharihari seperti kebutuhan makan, dan tempat tinggal. Seorang yang mempunyai pendapatan kurang akan berpengaruh kepada daya memberi seseorang dan akan berdampak pada lingkar lengan atas ibu hamil. Hal ini sesuai dengan teori tingkat pendapatan dapat menentukan pola makan, 
Pendapatan merupakan faktor yang paling menentukan kualitas dan kuantitas hidangan. Semakin banyak mempunyai uang berarti semakin baik makanan yang diperoleh dengan kata lain semakin tinggi penghasilan, semakin besar pula persentase untuk membeli buah, sayuran dan beberapa jenis bahan makanan lainnya yang akan berpengaruh kepada lingan lengan atas (Mandriawati,G.A. (2011).

Faktor yang berpengaruh pada Berat bayi lahir adalah umur ibu, sesuai hasil penelitian tabel 5.4 hampir setengahnya $(39,4 \%)$ ibu melahirkan bayi dengan berat badan lahir rendah . Ibu erat kaitannya dengan berat bayi lahir, kehamilan dibawah umur 20 tahun merupakan kehamilan berisiko tinggi, 24 kali lebih tinggi di bandingkan dengan kehamilan pada wanita yang cukup umur. Pada umur yang masih muda, perkembangan organ-organ reproduksi dan fungsi fisiologinya belum optimal. Selain itu emosi dan kejiwaannya belum cukup matang, sehingga pada saat kehamilan ibu tersebut belum dapat menanggapi kehamilannya secara sempurna dan sering terjadi komplikasi. Semakin muda usia ibu hamil akan mengakibatkan komplikasi salah satunya adalah berat badan bayi lahir. hal ini sesuai dengan teori (Setianingrum, S.I.W. 2005 ) yang menyatakan bahwa ibu hamil perlu mendapatkan tambahan gizi yang banyak karena selain digunakan untuk pertumbuhan dan perkembangan dirinya sendiri juga harus berbagi dengan janin yang dikandungnya.

Berdasarkan hasil penelitian dari 33 responden di BPS Artiningsih Surabaya didapatkan hampir sebagian besar $(72,8 \%)$ ibu hamil melahirkan dengan jarak yang terlalu dekat. Pada kehamilan yang perlu diwaspadai adalah jarakpe rsalinan terakhir dengan awal kehamilan sekarang kurang dari
2 tahun, bila jarak terlalu dekat, maka rahim dan kesehatan ibu belum pulih dengan baik. Pada keadaan ini perlu diwaspadai kemungkinan pertumbuhan janin kurang baik (seperti terjadinya BBLR), Hal ini sesuai dengan teori Menurut Dinkes (2010) yang mengatakan bahwa jarak terlalu dekat akan mempengaruhi pada pertumbuhan dan perkembangan bayi yang dikandung.

Berdasarkan hasil penelitian dari 33 responden di BPS Artiningsih Surabaya didapatkan hampir sebagian besar ibu hamil $(51,6 \%)$ melahirkan $>4$ anak. Jumlah anak $>4$ orang perlu diwaspadai kemungkinan persalinan lama, karena makin banyak anak, rahim ibu makin lemah yang akan berpengaruh pada berat badan bayi lahir. Hal ini sesuai dengan teori Menurut Dinkes (2010) bahwa kehamilan grande multipara akan mempengaruhi berat badan bayi lahir.

\section{Berat Badan Lahir}

Berdasarkan hasil penelitian tabel 5.8 dari 33 responden di BPS Artiningsih Surabaya didapatkan sebagian besar $(54,5 \%)$ responden mengalami berat badan bayi rendah. Pencegahan berat badan bayi lahir rendah sangat penting dengan pemeriksaan prenatal yang baik dan memperhatikan gizi ibu. Penanganan dan pemberian asuhan yang baik dapat menurunkan angka kesakitan dan kematian BBLR. faktor-faktor yang mengakibatkan berat badan bayi rendah adalah hampir setengahnya $(39,4 \%)$ umur ibu hamil pada usia dibawah usia $<20$ tahun. Umur yang muda perlu tambahan gizi yang banyak karena selain digunakan untuk pertumbuhan dan perkembangan dirinya sendiri juga harus berbagi dengan janin yang dikandungnya. sedangkan kehamilan pada usia > 35 tahun kesehatan dan 
keadaan rahim tidak sebaik seperti pada umur 20 - 35 tahun sebelumnya, hingga perlu diwaspadai terjadinya berat badan lahir rendah. Hal ini sesuai dengan teori (Setianingrum, S.I.W. 2005) bahwa kehamilan pada ibu usia $<20$ tahun akan mempengaruhi pertumbuhan bayi dalam kandungan.

\section{Hubungan lingkar lengan atas dengan berat badan bayi lahir}

Berdasarkan hasil uji Rank Sperman $\mathrm{p}=0,000<0,05$ yang menyatakan bahwa ada hubungan antara lingkar lengan atas dengan berat badan bayi lahir. (LILA) adalah antropometri yang dapat menggambarkan keadaan status gizi ibu hamil dan untuk mengetahui resiko (KEK) atau gizi kurang. Dengan lingkar lengan atas yang kurang dari 23,5 $\mathrm{cm}$ akan berisiko untuk melahirkan berat badan bayi lahir rendah, karena nutrisi yang dikonsumsi oleh ibu hamil sebagai ukurannya adalah lingkar lengan atas, sehingga lingkar lengan atas yang kurang akan mendapatkan bayi yang mempunyai BBLR. Hal ini sesuai dengan teori (Kristyana sari tahun 2010) yang mengatakan bahwa ibu yang memiliki ukuran lingkar lengan atas dibawah $23,5 \mathrm{~cm}$ beresiko melahirkan bayi BBLR.

\section{KESIMPULAN}

1. Ibu hamil dengan lingkar lengan atas di BPS Artiningsih Surabaya sebagian besar adalah kurang

2. Bayi lahir di BPS Artiningsih Surabaya sebagian besar mempunyai berat badan lahir rendah

3. Ada hubungan antara lingkar lengan atas ibu hamil dengan berat badan bayi lahir di BPS Artiningsih Surabaya

\section{DAFTAR PUSTAKA}

Kristiyanasari, Weni.(2010). Gizi Ibu
Hamil. Yogyakarta, Nuba Medika Supariasa

D.N. (2012). Penilaian Status Gizi, Jakarta, EGC Paath,E.F.(2005). Gizi Dalam Kesehatan Reproduksi, Jakarta, EGC Mandriawati,G.A. (2011). Asuhan Kebidanan Antenatal, Jakarta, EGC

Setianingrum, S.I.W. (2007). Hubungan Antara kenaikan Berat Badan, Lingkar Lengan Atas, dan Kadar Hemoglobin Ibu Hamil Trimester III dengan Berat Bayi Lahir di Puskesmas Ampel 1 boyolali tahun 2005. KTI, Semarang, Universitas Negeri Semarang. Jurnal-ibu-hamil, http/jurnal.unnes.ac.id/sju/ index.php/fsee, 28 juli 2014

Ferial, E.W. 2011. Hubungan Antara Status Gizi Ibu Berdasarkan Lingkar Lengan Atas (LILA) dengan Berat Badan Bayi Lahir di RSUD Daya Kota Makasar.

J.Med, Nus. 2005. Hubungan Antara Berat Badan Lahir dengan Status Gizi Berdasarkan Lingkar Lengan Atas, http : //med.unhas.ac.id. Diakses tanggal 3 Maret 2014

Mutalazimah.2010. Hubungan Lingkar Lengan Atas (LILA) dan Kadar Hemoglobin (Hb) Ibu Hamil dengan Berat Bayi Lahir Di RSUD Dr. Moerwardi Surakarta.

Saimin, J. 2006. Hubungan Antara Berat Badan Lahir Dengan Status Gizi Ibu Berdasarkan Ukuran Lingkar Lengan Atas. Bagian Obstetri dan Ginekologi Fakultas Kedokteran Universitas Hasanudin, Makasar

Rochjati, Poedji. (2006). Skirining Antenatal Pada Ibu Hamil, Pengendalian Faktor Resiko, Deteksi Dini Ibu Hamil Resiko Tinggi. Surabaya, Erlangga

Nanney, Vivian, (2010). Asuhan 
Neonatal Bayi dan Anak Balita. Jakarta: Salemba Medika

Budiman, C.(2011). Kolerasi Antara Berat Badan Ibu Hamil dengan Berat Badan Bayi Lahir, http://eprints.undip.ac.id/32931/1/ Charies pdf (Diakses pada tanggal 18 Mei 2013)

Joeharno (2008). Berat Badan Lahir Rendah (BBLR) http://blogjoeharno blogspot. com (Diakses pada tanggal 20 April 2013) 